\title{
"Hot” Zircons from the Merlin Kimberlite Field, Northern Territory, Australia
}

\author{
Brent I.A. McInnes ${ }^{1,2}$, Noreen J. Evans ${ }^{1,2}$, Brad J. McDonald ${ }^{1,2}$ and Janusz Jakimowicz ${ }^{3}$ \\ ${ }^{1}$ CSIRO Exploration \& Mining, Kensington, Western Australia \\ ${ }^{2}$ John de Laeter Centre for Mass Spectrometry, Curtin University, Western Australia \\ ${ }^{3}$ North Australian Diamonds Ltd., East Perth, Western Australia
}

\begin{abstract}
Introduction
Kimberlites and lamproites are volatile-rich, potassic ultramafic magmas that form at depths in excess of 150 $\mathrm{km}$. They ascend to the surface rapidly (time spans of hours to days), entraining mantle and crustal wall rock fragments along the way. If diamondiferous portions of the mantle are transgressed, diamonds will be transported to the Earth's surface. Similarly, zircon and other U-bearing minerals will be entrained in the erupting magma during transit through the crust, and will also be transported to the surface.
\end{abstract}

Current diamond exploration strategies include the search for kimberlite indicator minerals (KIMS) such as chromite, garnet and $\mathrm{Cr}$-diopside in stream sediments and soil samples. KIMS are, however, prone to chemical dissolution in tropical weathering conditions. Therfore, alternative approaches involving the geochemical analysis of resistant minerals such as zircon would enhance exploration success in tropical regions such as Australia, India and Brazil.

\section{Background}

Zircons begin to retain $\mathrm{Pb}$ when they cool below about $900^{\circ} \mathrm{C}$ so $\mathrm{U} / \mathrm{Pb}$ ages generally record the age of formation of the grain. However, because helium readily diffuses out of zircon at temperatures above $180^{\circ} \mathrm{C}$ (Reiners et al., 2002), zircon that originates from mid- to lower-crustal levels will not retain the radiogenic helium produced during the radioactive decay of naturally occurring $U$ and $T h$ :

${ }^{238} \mathrm{U} \rightarrow{ }^{206} \mathrm{~Pb}+8{ }^{4} \mathrm{He}$

${ }^{235} \mathrm{U} \rightarrow{ }^{207} \mathrm{~Pb}+7{ }^{4} \mathrm{He}$

${ }^{232} \mathrm{Th} \rightarrow{ }^{208} \mathrm{~Pb}+6{ }^{4} \mathrm{He}$

This means that mid- to lower-crustal zircons will have young (U-Th)/He ages (Figure 1). In contrast, upper crustal zircons will have very high contents of radiogenic helium (and old (U-Th)/He ages) because all of the ${ }^{4} \mathrm{He}$ atoms produced over time have been locked into this "cooler" zircon structure $\left(\mathrm{T}<180^{\circ} \mathrm{C}\right)$.
The result is that kimberlitic and lamproitic zircons from the mid- to lower-crust will have a markedly different $\mathrm{U}-\mathrm{Th}-\mathrm{Pb}-\mathrm{He}$ age to zircons eroded from the upper crust. In fact, the zircon (U-Th)/He age populations should be bimodal where zircons are sampled from all crustal depths (Figure 1). This work reports the results of $\mathrm{U}-\mathrm{Th}-\mathrm{Pb}-\mathrm{He}$ dating of samples obtained from the Merlin Kimberlite, Northern Territory, Australia.

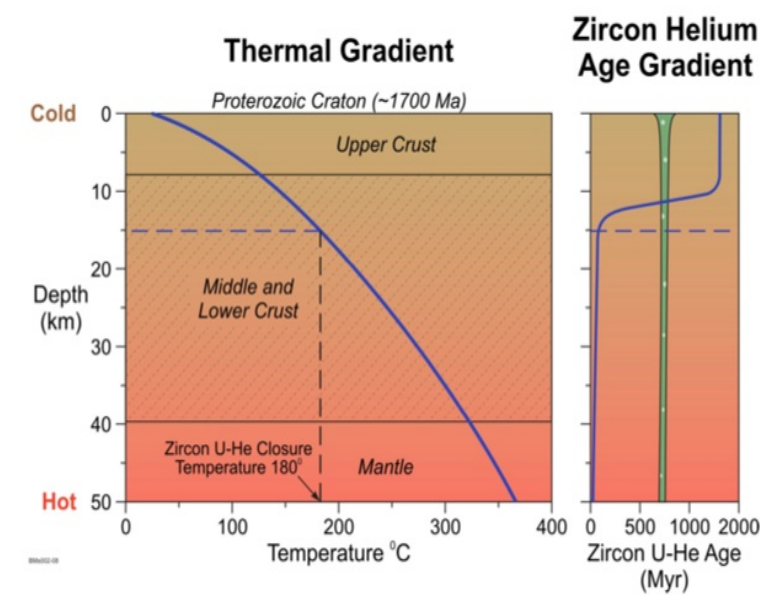

Figure 1. Helium retention in zircon is temperature dependent and controlled primarily by the Earth's geothermal gradient. Zircon grains from the lower- to mid-crustal regions entrained within a kimberlite eruption ("hot" zircon) will have ages equivalent to the eruption age of the kimberlite, whereas upper crustal zircons ("cold" zircon) will have cratonic ages. In this hypothetical example where a kimberlite eruption occurred today in a Proterozoic craton, the U-He age distribution of zircon xenocrysts would be either 0 for "hot" zircons transported from great depth or 1700 Myr for "cold" zircons transported from relatively shallow levels. 


\section{Samples and Methods}

The Merlin kimberlite deposits are hosted within the Early Cambrian Bukalara Sandstone (Muir, 1980). We separated zircon from: (i) a bulk sample of the Sacramore kimberlite pipe in the Merlin kimberlite field and (ii) a core sample of unmineralized Bukalara Sandstone located approximately $10 \mathrm{~km}$ from the kimberlite. Individual zircons were mounted in epoxy and polished to expose a surface suitable for SHRIMP analysis in the John de Laeter Centre of Mass Spectrometry, Curtin University of Technology, Perth, Australia. The zircon standard BR266 (559.1Ma, ${ }^{206} \mathrm{~Pb} /{ }^{238} \mathrm{U}=0.09059$; Stern 2001$)$ was used to calibrate $\mathrm{U}-\mathrm{Th}-\mathrm{Pb}$ isotopic ratios and elemental abundances. Corresponding ${ }^{206} \mathrm{~Pb} /{ }^{238} \mathrm{U}$ ages were corrected for common Pb using the 208 method (eg., Stern 1997).

Helium was thermally extracted from single crystals, heated using a $1064 \mathrm{~nm}$ Nd-YAG laser. ${ }^{4} \mathrm{He}$ abundances were determined by isotope dilution using a pure ${ }^{3} \mathrm{He}$ spike, calibrated daily against an independent ${ }^{4} \mathrm{He}$ standard. The uncertainty in the sample ${ }^{4} \mathrm{He}$ measurement is $<1 \%$. The $U$ and $\mathrm{Th}$ content of degassed apatite were determined by isotope dilution using ${ }^{235} \mathrm{U}$ and ${ }^{230} \mathrm{Th}$ spikes. Zircon was digested in Parr bombs using HF. Standard solutions containing the same spike amounts as samples were treated identically as were a series of unspiked reagent blanks. For single crystals digested in small volumes $(0.3-0.5 \mathrm{ml}), \mathrm{U}$ and $\mathrm{Th}$ isotope ratios were measured to a precision of $<2 \%$. Overall the $(\mathrm{U}-\mathrm{Th}) / \mathrm{He}$ thermochronology method at CSIRO has a precision of $2.5 \%$ and more detailed description of $U$ and $\mathrm{Th}$ analysis can be found in Evans et al. (2005). The zircon $(\mathrm{U}-\mathrm{Th}) / \mathrm{He}$ and $\mathrm{U} / \mathrm{Pb}$ ages were plotted using Isoplot/Ex 2.2 (Ludwig 2000).

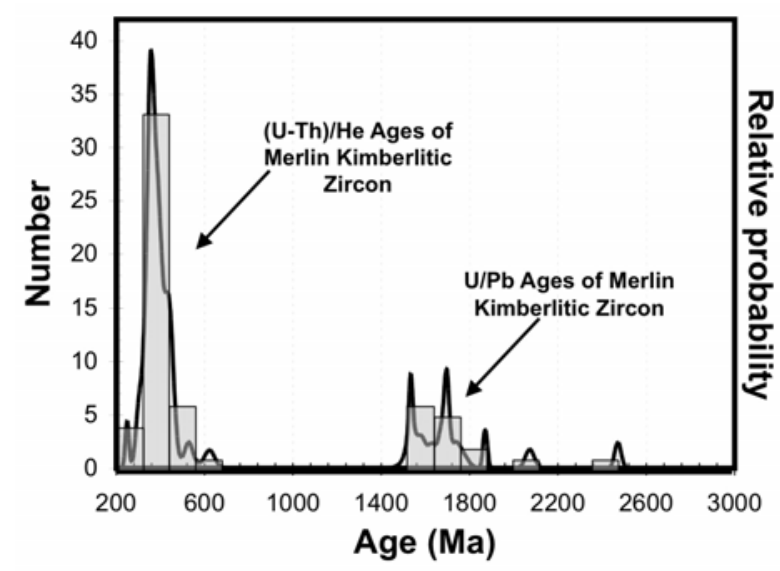

Figure 2. Zircon (U-Th)/He and $\mathrm{U} / \mathrm{Pb}$ ages for Merlin kimberlite displayed as a function of relative probability.

\section{Results}

The SHRIMP zircon $\mathrm{U} / \mathrm{Pb}$ ages for the Sacramore kimberlite $(n=14)$ range from 1500-2500 Ma (Figure
2), consistent with the Mesoproterozoic formation of the North Australian Craton and indicating that the zircons in the mineral separate obtained from the kimberlite are clearly of xenocrystic origin. That the mean $\mathrm{U} / \mathrm{Pb}$ age of zircon from the Bukalara Sandstone country rock is statistically indistinguishable from that of the Merlin kimberlite zircon (Figure 3) provides even more definitive evidence.

The Merlin kimberlitic zircon (U-Th)/He thermochronometry $(n=33)$ yielded a weighted average age of $368 \pm 18$ Ma (Figure 2), within error of previously determined $\mathrm{Rb} / \mathrm{Sr}(367 \pm 4 \mathrm{Ma})$ and ${ }^{40} \mathrm{Ar} /{ }^{39} \mathrm{Ar}$ (376-380 $\pm 4 \mathrm{Ma}$ ) dating of phlogopite model ages for the Merlin field (Lee et al., 1998; Hell et al., 2003). The $(\mathrm{U}-\mathrm{Th}) / \mathrm{He}$ results indicate that over $95 \%$ of the zircon grains from the Merlin kimberlite have helium ages equivalent to that of the age of emplacement of the diamondiferous kimberlites (367-380 Ma: Lee et al., 1998). This result suggests that the zircon xenocrysts could only have originated from mid- to deep-crustal protoliths where ambient temperatures exceeded the helium closure temperature for zircon $\left(\sim 180^{\circ} \mathrm{C}\right)$ at the time of eruption.

Because the majority of zircon grains from the Merlin kimberlite are "hot" zircons, with (U-Th)/He ages indicative of a deep crustal origin, helium thermochronology of zircon can potentially be used as a geochemical exploration tool for kimberlite deposits in tropical environments where chemical weathering destroys traditional KIM phases.

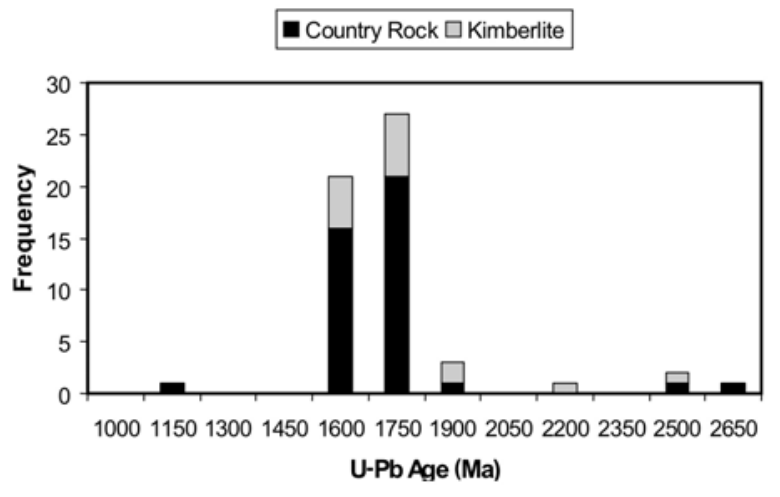

Figure 3. Zircon $\mathrm{U} / \mathrm{Pb}$ ages for Merlin kimberlite and Bukalara Sandstone country rock samples. The mean zircon $\mathrm{U}-\mathrm{Pb}$ ages of the kimberlite and country rock are $1735( \pm$ $250,2 \sigma)$ and $1637(( \pm 226,2 \sigma)$, respectively. The zircon age populations are statistically indistinguishable using Student's t test.

\section{References}

Evans, N.J., Byrne, J.P., Keegan, J.T. and Dotter, L.E. 2005. Determination of Uranium and thorium in zircon, apatite and fluorite: Application to laser (U-Th)/He thermochronology. J. Anal. Chem. 60. 1159-1165. 
Hell, A.J., Ramsay, W.R.H., Rheinberger, G. and Pooley, S. 2003. The geology, age, mineralogy and near surface features of the Merlin Kimberlites, Northern Territory, Australia. 8th International Kimberlite Conference, Vanouver. http://www.venuewest.com/8IKC/s1post.htm.

Lee, D.C., Reddicliffe, T.H., Scott Smith, B.H., Taylor, W.R., Ward, L.M. 1998. Merlin diamondiferous kimberlite pipes. In: Berkman D. A. \& Mackenzie D. H. eds. Geology of Australian and Papua New Guinean Mineral Deposits, pp. 461-464. The Australasian Institute of Mining and Metallurgy, Melbourne.

Ludwig, K.R. 2000. Isoplot/Ex version 2.2: a geochronological toolkit for Microsoft Excel. Berkeley Geochronology Center Special Publication 1a.

Muir, M.D. 1980. Paleontological evidence for the Early Cambrian age of the Bukalara Sandstone, McArthur Basin, NT. - BMR Jour. Austr. Geol. Geophys., 5 (2): 159-160.
Reiners, P.W., Farley, K.A. and Hickes, H.J. 2002. He diffusion and (U-Th)/He thermochronometry of zircon: Initial results from Fish Canyon Tuff and Gold Butte. Techtonophys. 349. 247-308.

Stern, R.A., 2001. A new isotopic and trace-element standard fort he ion microprobe: preliminary thermal ionization mass spectrometry (TIMS) U-Pb and electronmicroprobe data; Radiogenic Age and Isotopic Studies. Report 14, Geological Survey of Canada, Current Research 2001-F1, 11p.

Stern, R.A., 1997. The GSC Sentitive High Resolution Ion Microprobe (SHRIMP): Analytical Techniques of zircon U$\mathrm{Th}-\mathrm{Pb}$ age determinations and performance evaluation; In, Radiogenic Age and Isotopic Studies: Report 10; Geological Survey of Canada, Current Research 1997-F p. 1-31. 